\title{
PEMETAAN KUALITAS TIPE BATU BATA BERDASARKAN KOMPOSISI DAN BAHAN PEMBAKAR DI KABUPATEN BANTUL
}

\author{
Fadhilah S. A. Haryono' ${ }^{1}$, Yulianto P. Prihatmaji ${ }^{2 *}$ ) \\ *) Corresponding author email : prihatmaji@uii.ac.id
}

\begin{abstract}
1) Alumni Jurusan Arsitektur, Fakultas Teknik dan Perencanaan, Universitas Islam Indonesia, Jl. Kaliurang Km 14.5 Sleman, Yogyakarta

2) Jurusan Arsitektur, Fakultas Teknik dan Perencanaan, Universitas Islam Indonesia, Jl. Kaliurang Km 14.5, Sleman, Yogyakarta
\end{abstract}

\begin{tabular}{l} 
Article info \\
MODUL vol 21 no 1, issues period 2021 \\
\hline Doi $\quad: 10.14710 /$ mdl.21.1.2021.10-20 \\
Received $: 22$ juni 2020 \\
Revised $: 29$ september 2020 \\
Accepted $: 1$ maret 2021
\end{tabular}

\section{Abstract}

Batu bata adalah salah satu material yang telah banyak digunakan dalam pembangunan sekarang ini. Meski begitu, hal ini tentunya juga bergantung pada kualitas batu bata tersebut, yang ditentukan berdasarkan komposisi dan bahan pembakarnya. Berdasarkan hal tersebut, maka penelitian ini akan memetakan kualitas batu bata berdasarkan komposisi dan bahan pembakar di Bantul yang tanah dari Bantul dan Klaten, guna mempedalam pengetahuan material batu bata di Bantul serta pengujiannya, agar mempermudah dalam memilih batu bata yang berkualitas. Metode penelitian dilakukan dengan observasi langsung di lima kecamatan Bantul guna mengambil data dan sampel. Kemudian sampel dikelompokkan menjadi beberapa tipe dan dilakukan pengujian terhadap sampel berdasarkan standar. Pengelompokkan tersebut menghasilkan tujuh tipe batu bata berdasarkan komposisi dan bahan pembakar, dan didapatkan bahwa, batu bata terbaik adalah tipe 7 yang memiliki komposisi tanah, lempung, abu dan dibakar menggunakan sekam, kayu. Sedangkan pemetaan menunjukkan bahwa, batu bata yang baik kebanyakan berada di sisi timur peta.

Keywords: bahan pembakar; komposisi; kualitas; pemetaan batu bata

\section{PENDAHULUAN}

Pembangunan terus terjadi, dan salah satu material yang telah banyak digunakan dalam pembangunan adalah batu bata. Meskipun saat ini sudah banyak bermunculan material alternatif lain, ternyata masyarakat, terutama daerah Jawa masih banyak yang menyukai penggunaan batu bata (Rahmawati \& Saputro, 2015). Hal ini ternyata dikarenakan batu bata dari tanah liat ini memiliki harga yang murah, mudah diproduksi dan sifat-sifat unggul lain seperti memiliki ketahanan terhadap api, bahan kimia dan korosif serta berumur panjang (Gencel dkk., 2020). Batu bata sebagai bahan pengisi dinding non-struktural, ternyata juga memiliki keuntungan. Batu bata ini bisa meningkatkan kekuatan dari bangunan dan kerangka strukturnya (Maidiawati dkk, 2011). Bahkan saat gempat pada tahun 2007, Maidiawati dkk (2011) menemukan bangunan dengan dinding batu bata masih banyak yang bertahan. Oleh sebab itu, produsen batu bata masih banyak hingga sekarang, dan salah satunya adalah Bantul.

Bantul memiliki batu bata yang sudah cukup dikenal hingga ada pemesanan dari luar Bantul bahkan luar Yogyakarta. Hal ini disebabkan karena produksi di Bantul sudah ada sejak lama dan jumlahnya banyak, hal itu bisa dilihat dari data penambangan batu bata Bantul 2008 (Bapedal, 2008) yang sudah memiliki lima kecamatan penambangan batu bata dan totalnya bisa mencapai beberapa hektar. Kecamatan tersebut adalah Sewon, Kasihan, Banguntapan, Pleret dan Piyungan. Kelima kecamatan ini ternyata menggunakan komposisi dan bahan bakar yang berbeda-beda. Hal ini karena penggunaan ragam material dalam pembuatan dan pembakaran yang sesuai, memungkinkan peningkatan efektifitas dan kualitas (Wibowo \& Santosa, 2017; Rahmawati \& Saputro, 2015).

Menurut Handayani (2010), bata yang baik bisa didapatkan dari tanah kualitas baik atau dengan tambahan bahan lain guna menambah kekuatan. Selain itu, juga bisa didapatkan dari pembakaran yang optimal (Purwaningsih, 2006), dan pembakaran optimal ini salah satunya ditentukan oleh bahan pembakarnya (Syahland, 2016). Meski begitu, demi mendapatkan tanah yang baik, maka lokasi pengambilan tanah untuk batu bata juga penting (Kirkelund dkk, 2020). Berdasarkan pertimbangan tersebut, maka Bantul yang lokasi 
produsennya masih banyak yang berlokasi di tempat pengambilan tanah, sesuai dengan hal ini.

Berdasarkan hal tersebut, pembuatan batu bata Bantul yang menggunakan tanah yang sama, dengan bahan pembakar serta adanya penambahan bahan lain, memungkinkan memiliki kualitas berbeda antar areanya. Oleh sebab itu, maka penelitian ini akan membahas pemetaan kualitas batu bata tradisional di Bantul berdasarkan komposisi dan bahan pembakarnya, dikarenakan wilayah-wilayah di Bantul memiliki ciri berbeda antara sisi timur dan baratnya, dimana sisi timur masih kebanyakan menggunakan bahan bakar utama kayu, sedangkan sisi barat menggunakan bahan bakar beragam dengan penggunaan sekam padi.

Penelitian dilakukan di kelima kecamatan Bantul yang disebutkan Bapedal (2008). Kecamatan tersebut adalah Sewon (Desa Bangunharjo), Kasihan (Desa Tirtonirmolo), Pleret (Desa Bawuran), Banguntapan (Desa Wirokerten) dan Piyungan (Desa Sitimulyo). Hasil dari penelitian ini adalah pemetaan distribusi jenis batu bata berdasarkan lokasi yang telah diteliti, sehingga didapatkan peta kualitas batu bata berdasarkan pengujian dari standar yang dibedakan berdasarkan komposisi dan bahan pembakar di Kabupaten Bantul. Tujuannya adalah untuk pendalaman pengetahuan material batu bata di Bantul serta pengujiannya, sehingga mempermudah dalam memilih batu bata yang kuat dan tahan lama, jadi lebih efisien biaya dan tenaga bagi penggunanya.

\section{KAJIAN TEORI}

Bata-merah merupakan suatu bagian dari bangunan, yang dibuat dari tanah dengan atau tanpa campuran bahan-bahan lain dan dibakar dengan suhu cukup tinggi, hingga tidak dapat hancur lagi saat direndam dalam air (Direktorat Jenderal Ciptakarya, 1964). Batu bata yang baik, umumnya berbentuk persegi, pinggirannya lurus serta tajam, tidak ada retakan, tidak terlalu banyak gelembung dan tidak hancur saat direndam dalam air, serta tidak mudah patah saat dijatuhkan dari ketinggian 1,5 m (Silitonga dalam Rosalia, dkk., 2013 dalam Amir \& Basry 2019).

\section{Metode Produksi Bata-Merah}

Pembuatannya dimulai dengan memisahkan tanah liat dari lubang dan tambang, kemudian melepaskan batu dan menghancurkan gumpalan besar tanah liat dan ditambahkan air lalu dicampurankan hingga mudah dibentuk (Virdi, 2012). Terkadang, tanah liat-air ini memerlukan tambahan campuran guna memperbaiki kualitas, akibat tanah yang kurang baik (Handayani, 2010). Hal ini menunjukkan tanah bergantung pada lokasi, dan hal ini juga sesuai dengan penelitian yang dilakukan Kirkelund dkk (2020), dimana mereka mencoba menggunakan dua lempung berbeda yang berasal dari Denmark dan Greenland dan mendapatkan bahwa hasil dari Greenland memiliki porositas dan penyerapan air terendah. (Handayani, 2010).

Penambahan ini, contohnya bisa berupa abu sekam padi dapat meningkatkan kualitas batu bata dan menurunkan porositasnya (Amir dkk 2016 dalam Amir \& Basry, 2019). Ada juga yang menambahkan gergajian (Amir \& Basry, 2019) karena lebih ekonomis dan mudah didapat dibanding sekam (Handayani, 2010), Selain menambah kualitas, penambahan abu sekam padi ini juga bisa menghemat sumber daya tanah liat primer sehingga berkelanjutan, sekaligus mengurangi impor bahan baku sehingga juga baik untuk ekonomi (Kirkelund dkk, 2020). Campuran tanah liat-air maupun dengan campuran lainnya ini, kemudian dicetak menjadi batu bata, atau dikenal sebagai proses pembentukan (Virdi, 2012), yang kemudian dikeringkan.

Langkah selanjutnya adalah pembakaran yang dilakukan pada suhu $1000^{\circ} \mathrm{C}$ (Virdi, 2012) dengan waktu tujuh hari (Rahmawati \& Saputro, 2015). Pembakaran bata merupakan proses penting dan membutuhkan perlakuan khusus. Industri bata merah tradisional umumnya biasanya menggunakan bahan bakar kayu atau sekam padi (Purwaningsih, 2006). Dari hasil pembakaran tersebut, kualitas yang menggunakan bahan pembakar dari kayu memiliki kualitas lebih baik dibandingkan sekam padi (Syahland, 2016)

Pembakaran bata dengan bahan bakar kayu menggunakan lingga model rendeman kayu, yaitu bongkahan kayu diletakkan langsung di dalam lingga. Lingga merupakan susunan bata mentah kering yang siap dibakar. Sedangkan pembakaran bata dengan sekam padi menggunakan lingga model baris dan kolom, yaitu barisan bata dengan kolom kosong untuk sekam padi. Pembakaran bata akan optimal apabila kalor yang dibangkitkan tinggi/maksimal dibawah $2000^{\circ} \mathrm{C}$ dan kehilangan kalor lewat dinding tungku rendah. (Purwaningsih, 2006). Setelah pembakaran, batu bata dibiarkan hingga dingin sebelum dikemas. (Virdi, 2012)

\section{Syarat-syarat dan Pengujian \\ - Pandangan luar}

Bata-merah harus mempunyai rusuk-rusuk yang tajam dan siku, bidang-bidang sisi datar, tidak menunjukkan retak-retak dan perubahan bentuk yang berlebihan. Kemudian dilihat warnanya yang dinyatakan dengan merah tua, muda, kekuning-kuningan, kemerahmerahan, keabu-abuan, hitam dan sebagainya (Direktoral Jenderal Cipta Karya, 1964), Sedangkan berdasarkan standar SNI-03-41631996 (Amin, 2014), warna bata yang baik adalah oren kecoklatan, dan tekstur menurut ASTM C67-03 (Amin, 2014) adalah datar dan kasat. 


\section{- Ukuran-ukuran}

Pengujian dilakukan dengan mengukur panjang, lebar dan tebal batu bata berdasarkan standar (tabel 1).

Tabel 1. Ukuran batu bata (Olahan berbagai sumber)

\begin{tabular}{cc}
\hline \multicolumn{2}{c}{ Kuat tekan rata-rata kg/cm2 } \\
\hline NI-10 (1964) & SNI-15-2094-2000 \\
\hline A: 240x115x52 mm & M-5a. $\mathrm{p}=190 \pm 4, \mathrm{l}=90 \pm 3, \mathrm{t}=65 \pm 2$ \\
B: 230x110x50 mm & M-5b. $\mathrm{p}=190 \pm 4, \mathrm{l}=100 \pm 3, \mathrm{t}=65 \pm 2$ \\
$0-60$ & M-6a. $\mathrm{p}=230 \pm 4, \mathrm{l}=110 \pm 4, \mathrm{t}=52 \pm 3$ \\
& m-6b. $\mathrm{p}=230 \pm 5, \mathrm{l}=110 \pm 6, \mathrm{t}=55 \pm 2$ \\
\hline
\end{tabular}

Berdasarkan tabel tersebut, diketahui bahwa kedua standar ada yang memiliki kemiripan. Meski begitu, menurut SNI-03-4166-1996 (Amin, 2014), ukuran batu bata maksimal adalah panjang $400 \mathrm{~mm}$, lebar 75-300 $\mathrm{mm}$ dan tebal 50-200 mm. Kemudian, penyimpangan terbesar dari ukuran-ukuran standar adalah: panjang maksimum 3\%, lebar maksimum $4 \%$, tebal maksimum 5\%. Tetapi antara bata terbesar dan terkecil, selisih maksimum yang diperbolehkan adalah: panjang $10 \mathrm{~mm}$, lebar $5 \mathrm{~mm}$, tebal $4 \mathrm{~mm}$. Jumlah bendabenda yang boleh menunjukkan penyimpangan dalam ukuran-ukuran lebih dari penyimpangan maksimum yang telah ditentukan ialah (Direktorat Jenderal Ciptakarya, 1964):

a. Bata merah mutu tingkat I (satu) : tidak ada yang menyimpang.

b. Bata merah mutu tingkat II (dua) : satu buah dari sepuluh benda percobaan.

c. Bata merah mutu tingkat III (tiga) : dua buah dari sepuluh benda percobaan.

\section{- Kuat-tekan}

Dari tiap-tiap benda percobaan, kuat-tekannya tidak diperbolehkan 20\% lebih rendah dari harga ratarata terendah untuk tingkat mutunya (Direktorat Jenderal Ciptakarya, 1964).

Tabel 2. Kuat tekan batu-bata (Olahan berbagai sumber)

\begin{tabular}{ccc}
\hline Mutu bata- & \multicolumn{2}{c}{ Kuat tekan rata-rata kg/cm } \\
\cline { 2 - 3 } merah & NI-10 (1964) & SNI-15-2094-2000 \\
\hline Tingkat I & $>100$ & 50 \\
Tingkat II & $100-800$ & 100 \\
Tingkat III & $0-60$ & 150 \\
\hline
\end{tabular}

Berdasarkan tabel di atas, diketahui bahwa kedua kategori memiliki urutan berbeda dengan angka yang kurang lebih sama. Sedangkan menurut ASTM C-67-03 (Amin, 2014), di atur agar minimal memiliki kuat tekan sebesar $20 \mathrm{~kg} / \mathrm{cm}^{2}$.

\section{- Kadar garam yang larut dan membahayakan}

Benda-benda percobaan tidak boleh menunjukkan tanda-tanda yang menurut hasil pengujian dinyatakan membahayakan.

Hasil pengujian dinyatakan dengan kata-kata :

a. tidak membahayakan.

b. ada kemungkinan membahayakan.

c. membahayakan.

Pengujian kadar garam ini dilakukan dengan perendaman yang dilakukan dalam beberapa hari dan dilakukan berulang guna mendapatkan bunga-bunga putih yang menunjukkan kadar garam di dalamnya. Meski begitu, sebelum mendapat kadar garam, perendaman ini bisa digunakan untuk mendapatkan kapasitas penyerapan air serta bobot isi dari bata, yang hanya membutuhkan waktu 24 jam. Menurut SNI-034164-1996 (Amin, 2014), densitasnya adalah 1,60-2,50 gr/cm3. Selain itu, berdasarkan SNI-15-2094-2000 (Amir\&Basry, 2019) dan ASTM C-67-03 (Amin, 2014), porositas maksimalnya adalah 13-20 \% dan kadar air maksimal yang dilakukan dengan pemanasan adalah $15 \%$.

\section{METODE PENELITIAN}

Penelitian dilakukan pada bulan Sepetember sampai Desember 2016 di Sewon (Desa Bangunharjo), Kasihan (Desa Tirtonirmolo), Pleret (Desa Bawuran), Banguntapan (Desa Wirokerten) dan Piyungan (Desa Sitimulyo). Masing-masing desa dipilih 3-4 pengrajin secara acak, yang memiliki pengalaman 3 tahun ke atas.

Metode pengumpulan data dilakukan dengan observasi langsung dengan wawancara kepada pengrajin batu bata di masing-masing desa dan pengumpulan 5 sampel batu bata dari setiap pengrajin. Sampel batu bata yang didapatkan berjumlah 95 buah batu bata, yang jika dikelompokkan didapatkan 7 tipe batu bata (komposisibahan pembakar), yaitu :

1. Tanah - Kayu

2. Tanah, lempung - Kayu

3. Tanah, lempung - Sekam padi, gergajian

4. Tanah, lempung, sekam padi - Gergajian, kayu

5. Tanah, lempung, abu - Sekam padi, gergajian

6. Tanah, lempung, abu - Sekam padi, gergajian, kayu

7. Tanah, lempung, abu - Sekam padi, kayu

Berdasarkan tipe-tipe ini, didapatkan bahwa dari 95 batu bata, ada 20 batu bata tipe 1,15 batu bata tipe 2 , 15 batu bata tipe 3,15 batu bata tipe 4,15 batu bata tipe 5,10 batu bata tipe 6 dan 5 batu bata tipe 7 .

Kemudian, dari 7 tipe batu bata ini dilakukan pengujian berdasarkan syarat NI-10 yang kemudian dianalisi. Pengujian kualitas batu bata ini, sebenarnya ada berbagai macam, yaitu pandangan luar, ukuran, kuat tekan, kapasitas serapan air yang juga guna mengecek kadar garam laut yang membahayakan, serta kadar air 
dengan yang diuji dengan dipanaskan (Direktorat Jenderal Cipta Karya, 1964; Standar dalam Amin, 2014 dan Amir \& Basry, 2019). Meski begitu, beberapa metode memerlukan pengujian laboraturium serta peralatan yang mahal dan membutuhkan waktu, seperti uji kuat tekan dan kadar air, oleh sebab itu, pengujian ini akan diabaikan. Selain itu, pengujian kadar garam laut membahayakan digunakan untuk menguji tanah yang digunakan, tapi dalam penelitian ini, tanah berasal dari sumber yang sama, yaitu Bantul dan Klaten, oleh sebab itu, pengujian ini juga akan diabaikan.

Berdasarkan hal tersebut, pengujian-pengujian kuat tekan, kadar air, dan kandungan garam laut akan diabaikan. Meski begitu, berdasarkan syarat NI-10, diketahui bahwa pengujian kadar garam laut, bisa digunakan untuk mendapatkan kapasitas penyerapan dan bobot isi. Oleh sebab itu, dalam penelitian ini, hanya akan menggunakan pandangan luar, ukuran dan kapasitas serapan air guna mempermudah pengujian. Meski begitu, syarat kekuatan dari NI-10 belum terpenuhi. Maka, akan dilakukan uji tambahan guna mengetahui kekuatan batu bata, yaitu dengan menjatuhkan batu bata sehingga didapat pola pecahannya. Hal ini sesuai dengan pernyataan Silitonga dalam Rosalia, dkk (2013 dalam Amir \& Basry 2019), yaitu batu bata yang baik, salah satunya adalah tidak mudah patah saat dijatuhkan dari ketinggian 1,5 m. Jadi, pengujian yang dilakukan adalah pandangan luar dan ukuran (pengujian fisik), serta kapasitas serapan air dan pola jatuh (pengujian mekanik), lebih detailnya yaitu:

\section{Pandangan Luar}

Uji pertama yaitu dengan melihat permukaannya, dan guna mempermudah pengamatan, standar yang lebih difokuskan adalah SNI-03-415-1996 (SII dalam Amin, 2014), yaitu batu bata yang berwarna oren kecoklatan. Sedangkan menurut NI-10 (Direktoral Jenderal Cipta Karya, 1964), bata-merah harus mempunyai rusuk-rusuk yang tajam dan siku, bidang-bidang sisi datar, tidak mennunjukkan retak-retak dan perubahan bentuk yang berlebihan. Kemudian dilihat warnanya yang dinyatakan dengan merah tua, muda, kekuning-kuningan, kemerahmerahan, keabu-abuan, hitam dan sebagainya.

\section{Ukuran}

Pengujian ukuran dilakukan dengan mengukur setiap panjang, lebar dan tebal batu bata, yang dilakukan setidaknya sebanyak tiga kali (Gambar 1). Cara menghitungnya adalah seperti gambar di bawah ini :

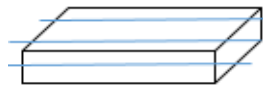

$P$



L

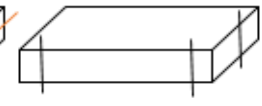

$\mathrm{T}$
Gambar 1. Cara Perhitungan Ukuran (Olahan dari NI10 1964, 2016)
Kemudian membandingkan ukuran dengan standar NI-10, yaitu:

- Bata merah : panjang $240 \mathrm{~mm}$, lebar $115 \mathrm{~mm}$, tebal $52 \mathrm{~mm}$.

- Bata merah : panjang $230 \mathrm{~mm}$, lebar $110 \mathrm{~mm}$, tebal $50 \mathrm{~mm}$.

Penyimpangan terbesar untuk panjang maksimum 3\%, lebar maksimum 4\%, tebal maksimum $5 \%$. Sedangkan selisih antar batanya untuk panjang 10 $\mathrm{mm}$, lebar $5 \mathrm{~mm}$, tebal $4 \mathrm{~mm}$. Jumlah benda-benda yang boleh menunjukkan penyimpangan dalam ukuranukuran lebih dari penyimpangan maksimum yang telah ditentukan akan menunjukkan mutu tingkat batu bata (Direktorat Jenderal Cipta Karya, 1964).

Kemudian, dari hasil ukuran perbandingan dan penyimpangan diberi poin satu sampai lima. Pemberian poin terbaik mendapat poin 5 , kedua mendapat poin 4 , ketiga mendapat poin 3 , keempat mendapat poin 2 dan kelima mendapat poin 1 . Sehingga, berdasarkan tipe dan uji tersebut didapatkan jenis batu bata yang berkualitas baik.

\section{Kapasitas penyerapan air}

Pengukuran kapasitas penyerapan air dilakukan dengan menimbang batu bata dalam kondisi kering (Wa), kemudian direndam. Perendaman batu bata dalam posisi berdiri untuk melihat waktu yang diperlukan masing-masing batu bata untuk menjadi basah sepenuhnya, kemudian batu bata direndam semalaman, dan keesokan harinya batu bata di timbang beratnya kembali. Penimbangan setelah basah dilakukan 2 kali, pertama saat benar-benar diambil dari air (Wb), dan kedua setelah agak dibiarkan dalam waktu kurang dari 3 menit (Wc) (Direktorat Jenderal Cipta Karya, 1964).

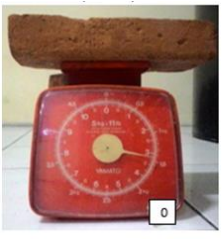

a

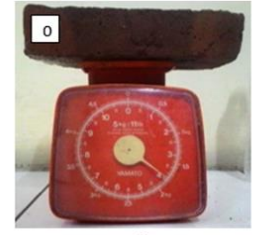

b

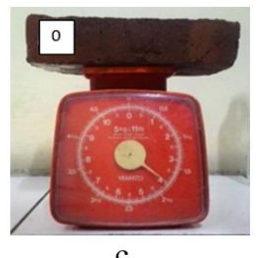

Gambar 2. Penimbangan batu bata saat (a) kering, (b) basah langsung diangkat, (c) basah sebelum 3 menit (Penulis, 2016)

Berdasarkan hasil penimbangan tersebut, selanjutnya dilakukan perhitungan penyerapan dengan rumus (Direktorat Jenderal Cipta Karya, 1964):

Penyerapan air $=\frac{W b-W a}{W a} \times 100 \%$

Rumus penyerapan air ini dilakukan guna mengetahui kapasitas penyerapan air yang didapat, dimana semakin tinggi penyerapan air, maka semakin 
ringan bobot isi batu bata tersebut, atau semakin rendah kualitasnya, dan standarnya adalah $<20 \%$ (Direktorat Jenderal Cipta Karya. Tapi, jika dilihat dari standar ASTM C-67-03 (Amin, 2014), maka standarnya adalah 13-20\%. Selanjutnya pengujian bobot isi, rumusnya yaitu (Direktorat Jenderal Cipta Karya, 1964):

Bobot isi $=\frac{W a}{W b-W c} \mathrm{~kg} / \mathrm{dm}^{3}$

Pengujian ini dilakukan untuk memastikan bobot isi batu bata tersebut, dimana semakin tinggi bobot isi, maka semakin padat atau kualitasnya semakin baik.

\section{Pola pecahan hasil jatuh}

Pola pecahan ini adalah pengujian tambahan yang tidak termasuk dalam NI-10. Caranya dengan menjatuhkan setiap batu bata dengan ketinggian $1 \mathrm{~m}$ dari permukaan yang sama, kemudian hasil jatuh batu bata di susun kembali agar mendapat pola pecahan dari tiap batu bata (Gambar 3).
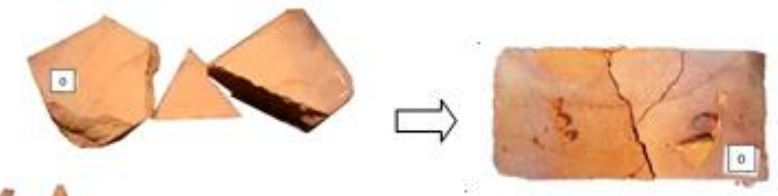

17.

Gambar 3. Pola pecahan sebelum dan sesudah disusun (Penulis, 2016)

Kemudian dari setiap pola yang didapat disesuaikan pembagian pola yang ditentukan, dan didapatkan ada 7 tipe pola, yaitu utuh, 3/4, 1/2, 1/3, 1/4, 1/6, dan $1 / 8$, dimana pola utuh adalah yang terbaik, dan semakin memburuk saat pola pecahannya banyak dan kecil-kecil (Gambar 4).

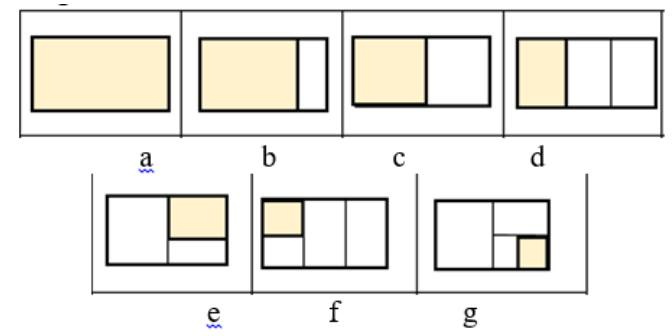

Gambar 4. Tipe pola pecahan (Penulis, 2016)

Berdasarkan tipe pola pecahan tersebut, kemudian dihitung persenannya, caranya adalah jumlah pecahan ditotal berdasarkan tipenya, kemudian dihitung dengan rumus : $\frac{\text { Total pola pecahan }}{\text { Jumlah batu bata }} \times$ model pola pecahan

Hasil persentase dari rumus tersebut kemudian digunakan untuk penentuan kualitas. Caranya dengan menjumlahkan persentase 2 pola pecahan terbesar dan juga 2 pola pecahan terkecil. Maka pola pecahan besar yang banyak dan diimbangin pola pecahan kecil yang sedikit dianggap memiliki kualitas yang baik. Lebih jelasnya bisa dengan menggunakan pemberian poin dimana yang terbaik mendapat poin 5 , kedua mendapat poin 4 , ketiga mendapat poin 3 , keempat mendapat poin 2 dan kelima mendapat poin 1. Sehingga, berdasarkan tipe dan uji tersebut didapatkan jenis batu bata yang berkualitas baik.

\section{Analisis keseluruhan}

Berdsasarkan 4 uji coba tersebut, diketahui bahwa pengujian pandangan luar dan ukuran merupakan pengujian fisik, dan pengujian ukuran bernilai kuantitatif sehingga lebih valid. Maka, 3 pengujian kuantitatif, yaitu ukuran, kapasitas serapan air dan pola pecahan, akan diberi poin guna mendapatkan urutan batu bata berdasarkan kualitasnya. Pemberian angka dengan cara pemberian poin berdasarkan peringkat. Hasil dari setiap uji coba diberi poin, untuk peringkat pertama adalah 5 , kedua adalah 4, ketiga adalah 3, keempat adalah 2 dan kelima adalah 1. Maka didapatkan hasil dengan jumlah poin yang semakin besar memiliki kualitas yang semakin baik. Kemudian hasilnya dipetakan dan juga pengelompokkan komposisi dan bahan bakar yang dilakukan, dibandingkan dengan penelitian sebelumnya.

\section{HASIL DAN PEMBAHASAN}

Penelitian di Desa Bangunharjo (Kecamatan Sewon) dan Desa Tirtonirmolo (Kecamatan Kasihan) menunjukkan bahwa kedua desa masih memiliki sumber bahan mentahnya, sehingga tanah langsung diambil dari lokasinya, meski ada yang menggunakan tambahan lempung yang merupakan kiriman dari Klaten. Sedangkan bahan pembakar yang digunakan adalah kayu.

Pendelitian untuk Desa Bawuran (Kecamatan Pleret), Desa Wirokerten (Kecamatan Banguntapan) dan Desa Sitimulyo (Kecamatan Piyungan), ketiganya berada di tempat lempun bisa didapatkan, tetapi tanah merupakan kiriman dari Klaten. Sealain itu, ketiga tempat produksi ini menggunakan sekam padi sebagai bahan utama pembakaran. Sedangkan untuk cara pembuatannya, kelima tempat ini memiliki cara atau tahapan yang sama. 
Tabel 3. Lokasi-Bahan Pembuatan-Bahan Pembakaran (Penulis, 2016)

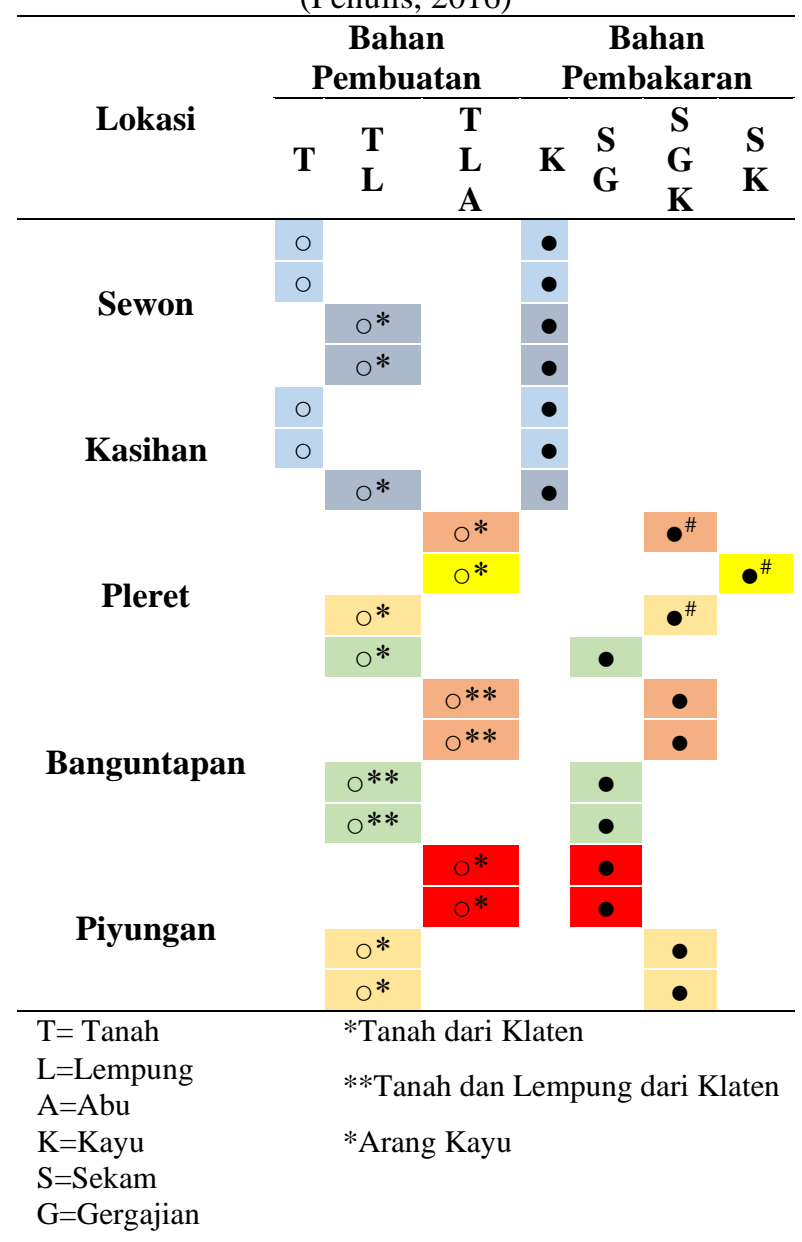

Pengelompokkan berdasarkan komposisi dan bahan pembakar, didapat ada 7 tipe batu bata (komposisi-bahan pembakar) yang bisa dilihat pada tabel 4.

Tabel 4. Tipe Batu Bata (Penulis, 2016)

\begin{tabular}{cccc}
\hline Tipe & Komposisi & Bahan Pembakar & Jumlah \\
\hline $\mathbf{1}$ & Tanah & Kayu & 20 \\
$\mathbf{2}$ & Tanah, lempung & Kayu & 15 \\
$\mathbf{3}$ & Tanah, lempung & Sekam padi, gergajian & 15 \\
& Tanah, lempung & Sekam padi, gergajian, & 15 \\
$\mathbf{4}$ & kayu & \\
$\mathbf{5}$ & Tanah, lempung, abu & Sekam padi, gergajian & 15 \\
& & Sekam padi, gergajian, & 10 \\
$\mathbf{6}$ & Tanah, lempung, abu & kayu & \\
7 & Tanah, lempung, abu & Sekam padi, kayu & 5 \\
\hline
\end{tabular}

Berdasarkan ketujuh tipe ini, kemudian dilakukan pengujian sesuai standar.

\section{Pandangan Luar}

Pengujian pertama dengan melihat permukaannya, lebih jelasnya bisa dilihat pada tabel 5 yang menunjukkan 1 sampel dari masing-masing pengrajin.

Tabel 5. Permukaan batu bata (Penulis, 2016)

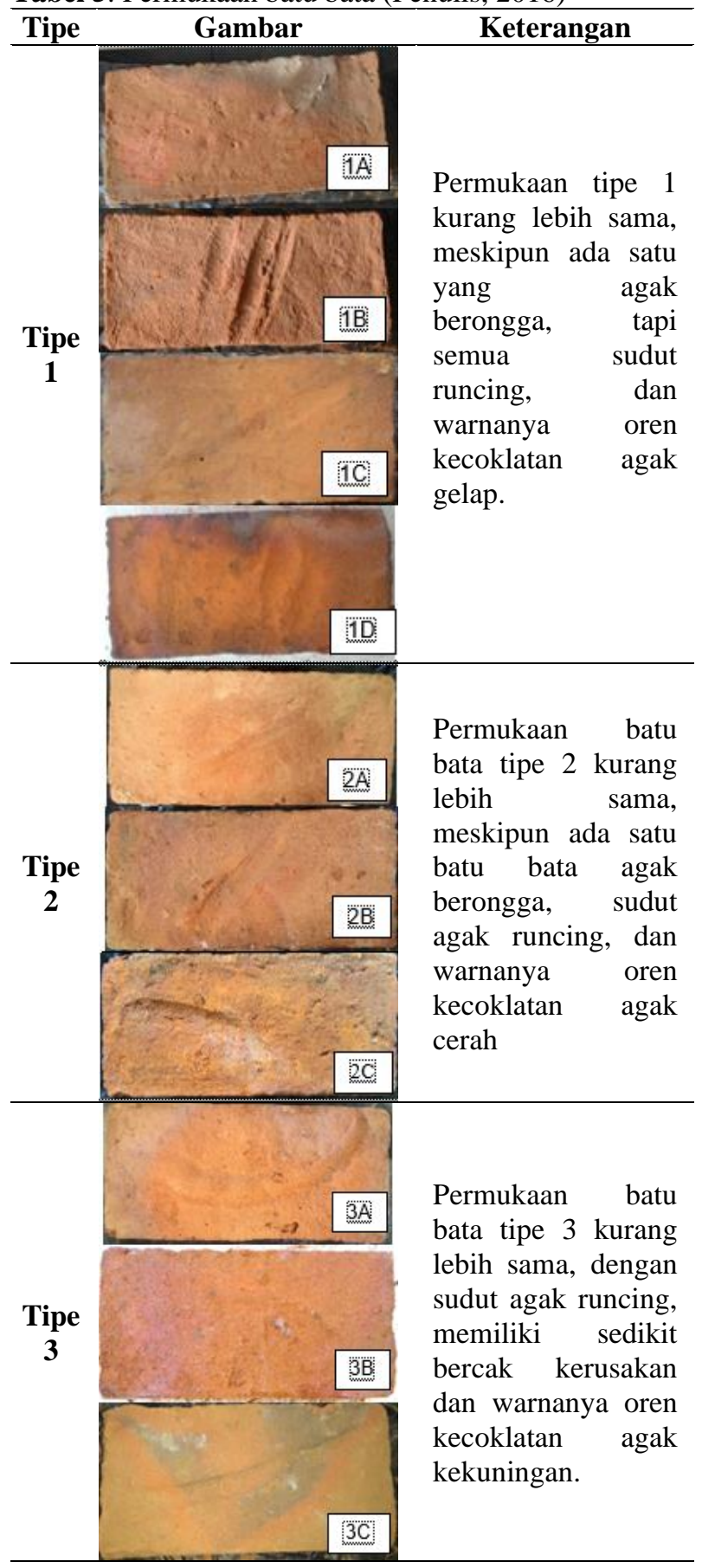




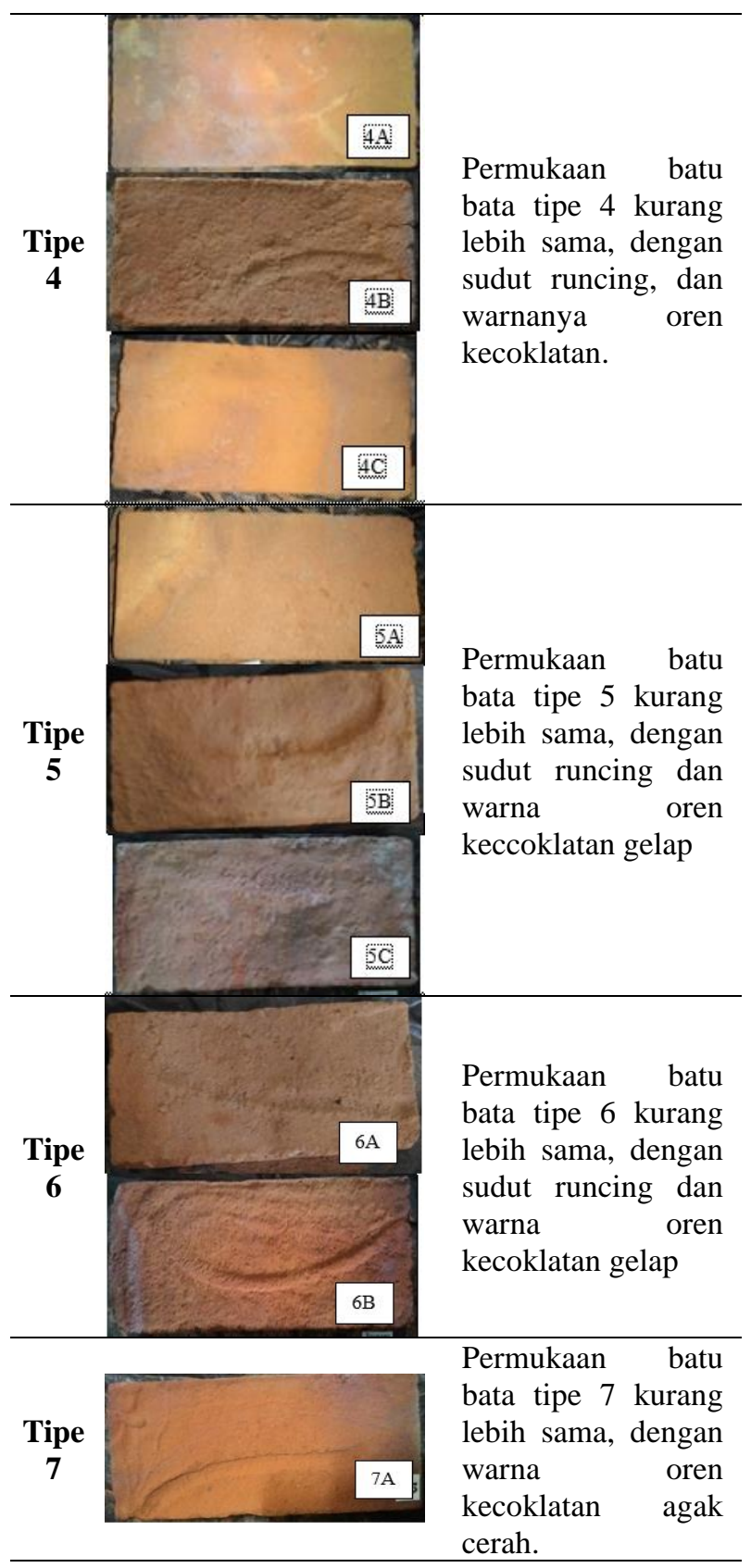

Berdasarkan warna dan permukaan di atas, didapat bahwa semua tipe batu bata memiliki permukaan yang kurang lebih sama dengan warna oren kecoklatan dengan pembeda kecerahan, meskipun tipe 3 memiliki sedikit bercak kerusakan.

\section{Ukuran}

Uji kedua adalah uji ukuran, yang dibandingkan dengan standar NI-10 tipe II, karena memiliki ukuran yang lebih mendekati ukuran batu bata yang diteliti, yaitu panjang $230 \mathrm{~mm}$, lebar $110 \mathrm{~mm}$, tebal $50 \mathrm{~mm}$. Sedangkan ukuran penyimpangan terbesar untuk panjang maksimum 3\%, lebar maksimum 4\%, tebal maksimum 5\% (Gambar 5).

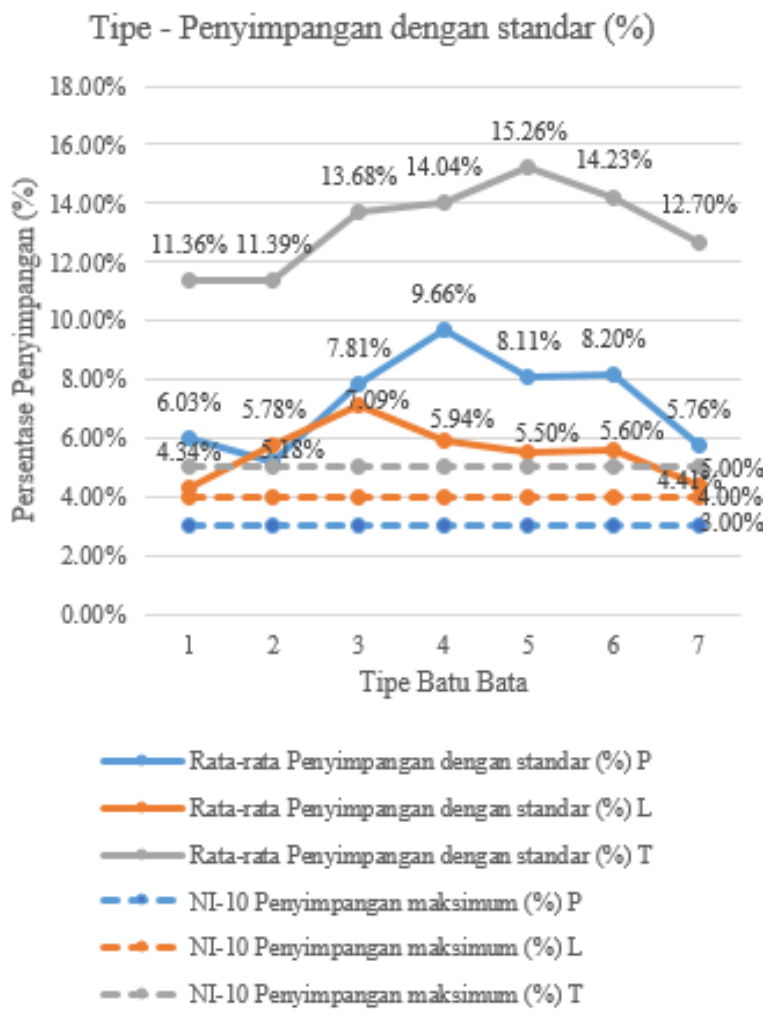

Gambar 5. Grafik Tipe-Penyimpangan dengan Standar (Penulis, 2016)

Berdasarkan grafik pada gambar 5 didapatkan bahwa semua tipe memiliki penyimpangan melebihi standar yang ditetapkan. Jadi, semua batu bata termasuk golongan batu bata mutu III. Meski begitu, yang paling mendekati standar secara berurutan adalah batu bata tipe 1 , tipe 7 , dan tipe 2 .

Ketiga tipe ini menggunakan komposisi berbedabeda, meski begitu ketiganya menggunakan kayu maupun ada tambahan kayu dalam pembakarnya. Selain itu, tipe 1 dan tipe 2 berada di lokasi barat peta yang kemungkinan memang memliki ukuran lebih mendekati standar. Sedangkan, tipe 7 berasal dari lokasi timur peta yang mungkin memiliki ukuran berbeda dengan lokasi barat. Lokasi di timur ini juga memiliki bahan pembakar yang beragam jenis, dan tipe 7 dengan bahan pembakar sekam dan kayu memiliki skor tertinggi di antara lainnya. Hal ini menunjukkan bahwa kayu memungkinkan pengurangan susutan yang diakibatkan pembakaran.

Selanjutnya, pengujian ukuran antar batu bata tiap-tiap tipe berdasarkan NI-10 adalah menghitung selisih antar batanya, untuk panjang $10 \mathrm{~mm}$, lebar $5 \mathrm{~mm}$, tebal $4 \mathrm{~mm}$. 


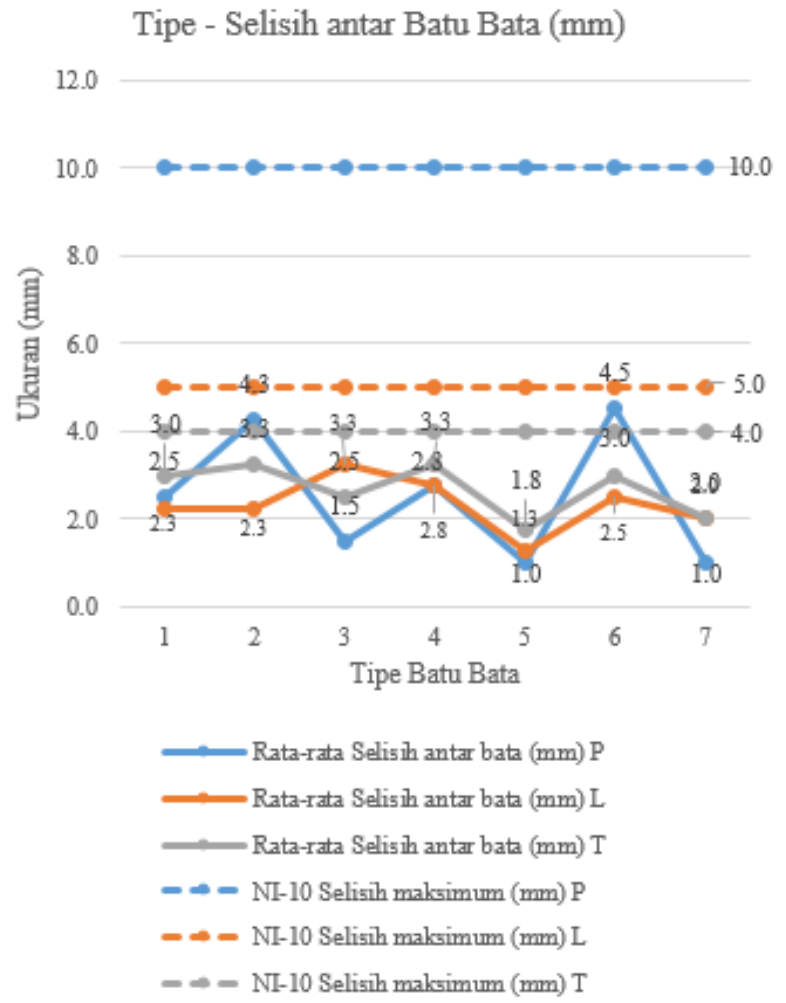

Gambar 6. Grafik Tipe-Selisih antar Batu Bata (Penulis, 2016)

Berdasarkan grafik pada gambar 6 didapatkan bahwa semuanya memenuhi standar untuk selisih antar batu bata, yang artinya semua batu bata mengalami sedikit penyusutan dalam pembakaran, sehingga mengurangi resiko batu bata retak ataupun melengkung yang bisa mengurangi kekuatan batu bata. Meski begitu terdapat urutan yang menunjukkan selisih terkecil, yaitu pertama adalah tipe 5, kedua adalah tipe 7 , dan ketiga adalah tipe 3 .

Ketiga tipe tertinggi ini menggunakan komposisi dan bahan pembakar campuran. Hal ini menunjukkan bahwa tanah yang digunakan sudah kurang baik sehingga memerlukan campuran dalam pembuatan batu bata. Sedangkan bahan pembakar ketiganya menggunakan bahan pembakar utama berupa sekam padi.

Hasil dari kedua uji ukuran menghasilkan peringkat kualitas yang berbeda. Meski begitu, akan diberikan poin berdasarkan peringkat guna mengetahui kualitas berdasarkan ukuran. Pemberian poin tersebut adalah yang memiliki peringkat pertama sampai kelima mendapat 5 poin, kedua mendapat 4 poin dan ketiga mendapat 3 poin, keempat mendapat 2 poin dan kelima mendapat 1 poin (Tabel 6).
Tabel 6. Urutan kualitas uji ukuran (Penulis, 2016)

\begin{tabular}{|c|c|c|c|c|c|c|c|}
\hline \multirow{2}{*}{ Tipe } & \multicolumn{3}{|c|}{ Penyimpangan } & \multicolumn{3}{|c|}{ Selisih } & \multirow{2}{*}{ Jumlah } \\
\hline & $\mathbf{P}$ & $\mathbf{L}$ & $\mathbf{T}$ & $\mathbf{P}$ & $\mathbf{L}$ & $\mathbf{T}$ & \\
\hline 1 & 3 & 5 & 5 & 2 & 3 & 2 & 20 \\
\hline 2 & 5 & 1 & 4 & & 3 & & 13 \\
\hline 3 & 2 & & 2 & 3 & & 3 & 10 \\
\hline 4 & & & 1 & 2 & & & 3 \\
\hline 5 & 1 & 3 & & 5 & 5 & 5 & 19 \\
\hline 6 & & 2 & & & 1 & 2 & 5 \\
\hline 7 & 4 & 4 & 3 & 5 & 4 & 4 & 24 \\
\hline
\end{tabular}
peringkat terbaik adalah batu bata tipe 7 , kedua adalah tipe 1 dan ketiga adalah tipe 5 .

Ketiga tipe ini memiliki jenis komposisi maupun pembakar yang berbeda-beda. Meski begitu, jika dilihat dari bahan pembakarnya, tipe 7 dan 1 menggunakan kayu dan tambahan kayu dalam bahan pembakarnya, dan tipe 5 tidak. Kemudian, jika dilihat dari komposisinya, tipe 5 dan 7 memiliki komposisi sama, sehingga bahan pembakar dengan adanya penambahan kayu lebih baik. Sedangkan antara komposisi tanpa campuran (tipe 1) dengan campuran (tipe 7), ternyata lebih baik dengan campuran, yang menunjukkan bahwa tanah yang digunakan sudah kurang baik, sehingga memerlukan campuran dalam pembuatan batu bata.

\section{Kapasitas penyerapan air}

Uji ketiga adalah pengujian kapasitas penyerapan air, dan didapatkan hasil di gambar 7.

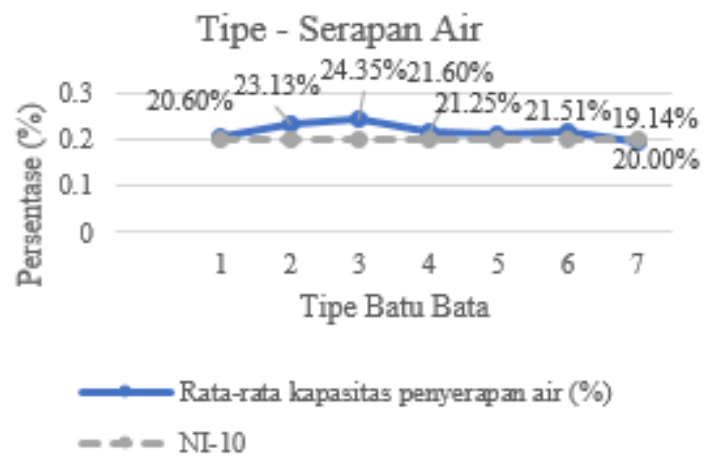

Gambar 7. Grafik Tipe-Serapan Air (Penulis, 2016)

Batu bata yang baik adalah yang memiliki kapasitas serapan air $<20 \%$. Berdasarkan grafik didapatkan bahwa batu bata yang memiliki kapasitas penyerapan air $<20 \%$ hanya tipe 7 . Sedangkan yang lain melebihi 20\%, meski begitu didapatkan bahwa urutan kapasitas penyerapan air seperti berikut, pertama adalah tipe 7, kedua adalah tipe 1, dan ketiga adalah tipe 5 .

Selanjutnya, dengan cara yang sama dengan uji serapan air tetapi penimbangan disaat basah dilakukan 2 kali, yang kedua adalah setelah agak dibiarkan kurang 
dari 3 menit. Kemudian dilakukan perhitungan bobot isi, dan didapatkan hasil yang bisa dilihat pada gambar 8 .

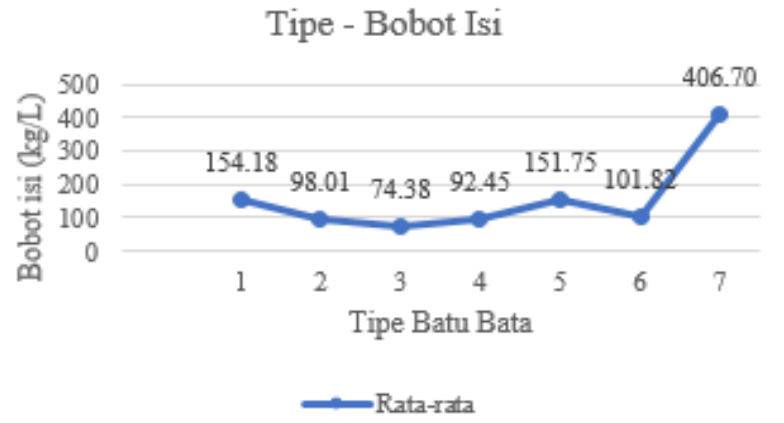

Gambar 8. Grafik Tipe-Bobot Isi (Penulis, 2016)

Berdasarkan grafik pada gambar 8 didapatkan bahwa bobot isi tertinggi adalah tipe 7. Maka tipe 7 memiliki kepadatan tertinggi dan memiliki mutu terbaik. Meski begitu didapat 3 urutan batu bata dengan kualitas terbaik, pertama adalah tipe 7 , kedua adalah tipe 1 dan ketiga adalah tipe 5 .

Kedua pengujian di kapasitas penyerapan air dan bobot isi, menunjukkan bahwa ketiga tipe batu bata terbaik sama dengan pengujian sebelumnya. Artinya, komposisi pembuatan batu bata menggunakan campuran lebih baik dari yang tanpa campuran dikarenakan tanah yang sudah kurang baik. Selain itu, adanya kayu dalam pembakaran memiliki hasil lebih baik dibanding tanpa kayu.

\section{Pola pecahan hasil jatuh}

Uji keempat berupa uji tambahan, yaitu uji pola jatuh batu bata dari 7 pola pecahan yang didapat, dimana pola a hingga g adalah dari utuh hingga semakin kecil, dan di dapat hasil persentase di tabel 7 .

Tabel 7. Total persentase pola pecahan batu bata

\begin{tabular}{cccccccc}
\multicolumn{7}{c}{ (Penulis, 2016) } \\
\hline $\mathbf{\%}$ & $\mathbf{a}$ & $\mathbf{b}$ & $\mathbf{c}$ & $\mathbf{d}$ & $\mathbf{e}$ & $\mathbf{f}$ & $\mathbf{g}$ \\
\hline $\mathbf{1}$ & & 6,3 & 41,7 & 27 & 8,3 & 8,3 & 10,4 \\
$\mathbf{2}$ & & 16,7 & 40,5 & & 16,7 & 5,6 & 9,7 \\
$\mathbf{3}$ & & 25 & 16,7 & 11,1 & 27,8 & 7,4 & 11,1 \\
$\mathbf{4}$ & 8,3 & 12,5 & 50 & 7,41 & & 3,7 & 11,1 \\
$\mathbf{5}$ & & & 61,1 & 18,5 & 5,6 & & 15,3 \\
$\mathbf{6}$ & & & 66,7 & 22,2 & 4,2 & & 10,4 \\
$\mathbf{7}$ & & 25 & 33,3 & 22,2 & 8,3 & & 12,5 \\
\hline
\end{tabular}

Berdasarkan tabel tersebut kemudian dilakukan penjumlahkan persentase 2 pola pecahan terbesar dan juga 2 pola pecahan terkecil yang kemudian diberi poin, sehingga bisa mendapatkan batu bata dengan kualitas yang baik. Hasil pemberian poin bisa dilihat pada tabel 8 di bawah ini.
Tabel 8. Urutan Kualitas Tipe Pecahan Batu Bata

\begin{tabular}{cccc}
\multicolumn{4}{c}{ (Penulis, 2016) } \\
\hline Tipe & $\begin{array}{c}\text { Pecahan } \\
\text { Besar }\end{array}$ & $\begin{array}{c}\text { Pecahan } \\
\text { Kecil }\end{array}$ & Jumlah \\
\hline $\mathbf{1}$ & 1 & & 1 \\
$\mathbf{2}$ & 2 & 2 & 4 \\
$\mathbf{3}$ & 5 & & 5 \\
$\mathbf{4}$ & 3 & 3 & 6 \\
$\mathbf{5}$ & & 2 & 2 \\
$\mathbf{6}$ & & 5 & 5 \\
$\mathbf{7}$ & 5 & 4 & 9 \\
\hline
\end{tabular}

Berdasarkan tabel 8, didapatkan bahwa batu bata terbaik adalah tipe 7, kedua 4, ketiga adalah tipe 3 dan 6 dan terendah adalah tipe 1 . Hasil pengujian ini menunjukkan bahwa, keseluruhan tipe dengan nilai baik memiliki komposisi campuran, serta bahan bakar dengan tambahan kayu didalamnya. Hal ini sesuai dengan pengujian sebelumnya, yang juga menunjukkan hasil serupa. Selain itu, seluruh tipe batu bata berada di sisi timur Bantul.

\section{Analisis keseluruhan}

Berdsasarkan 4 uji coba tersebut, maka dilakukan pemberian poin guna mengetahui kualitas terbaik. Hasil dari pemberian nilai tersebut bisa dilihat pada tabel 9 .

Tabel 9. Urutan Batu Bata berukualitas Baik (Penulis, 2016)

\begin{tabular}{ccccc}
\hline Tipe & Ukuran & $\begin{array}{c}\text { Kapasitas } \\
\text { air }\end{array}$ & $\begin{array}{c}\text { Pola } \\
\text { pecahan }\end{array}$ & Jumlah \\
\hline $\mathbf{1}$ & 4 & 4 & & 8 \\
$\mathbf{2}$ & 2 & 1 & 1 & 4 \\
$\mathbf{3}$ & 1 & & 3 & 4 \\
$\mathbf{4}$ & & & 4 & 4 \\
$\mathbf{5}$ & 3 & 3 & & 6 \\
$\mathbf{6}$ & & 2 & 3 & 5 \\
$\mathbf{7}$ & 5 & 5 & 5 & 15 \\
\hline
\end{tabular}

Hasil penjumlahan dari semua uji coba didapatkan bahwa batu bata yang memiliki kualitas terbaik adalah tipe 7, kedua tipe 1 dan ketiga adalah tipe 5. Berdasarkan 3 uji coba tersebut, jika dilihat dari lokasi, tipe 7 dan tipe 5 berada di sisi timur, sedangkan tipe 1 berada di sisi barat Bantul. Lebih jelasnya bisa dilihat pada pemetaan di gambar 9. 


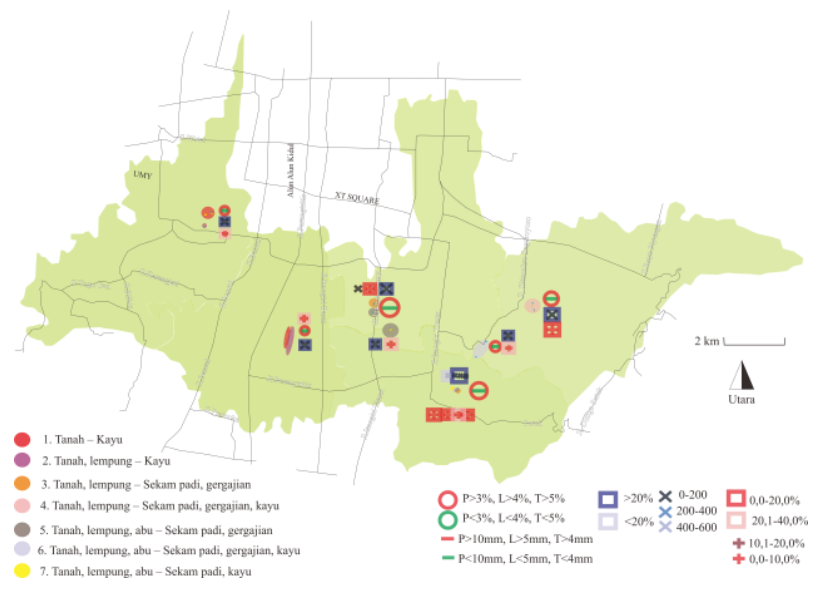

Gambar 9. Pemetaan Hasil Uji Coba (Penulis, 2016)

Pemetaan diurutkan dari hasil uji, yaitu kesesuaian ukuran, kapasitas air, dan pola pecahan. Hal ini dilakukan dengan cara pemberian warna muda untuk menunjukkan hasil yang sesuai standar. Maka didapatkan bahwa warna-warna muda banyak didapatkan disisi timur. Maka batu bata di sisi timur memiliki kualitas lebih baik.

Kemudian, jika dilihat dari 7 tipe yang ada, sebenarnya ada tiga jenis komposisi pembentuk batu bata (A), serta 4 jenis bahan pembakar (B), yaitu:

Tabel 10. Pengelompokkan Komposisi-Bahan Pembakar Batu Bata (Penulis, 2016)

\begin{tabular}{cccc}
\hline & Kelompok & Tipe & Keterangan \\
\hline \multirow{2}{*}{ A } & Tanah & 1 & Baik \\
& Tanah, lempung & $2,3,4$ & \\
& Tanah, lempung, abu & $5,6,7$ & Terbaik \\
\hline & Kayu & 1,2 & Baik \\
\multirow{2}{*}{ B Sekam padi, gergajian } & 3,5 & \\
& Sekam padi, gergajian, kayu & 4,6 & \\
& Sekam, kayu & 7 & Terbaik \\
\hline
\end{tabular}

Berdasarkan tabel di atas, maka diketahui bahwa komposisi campuran adalah yang paling sesuai di Bantul, dan komposisi tanah, lempung serta abu adalah yang terbaik. Sedangkan untuk bahan pembakar, pembakaran dengan kayu atau tambahan kayu memiliki hasil terbaik.

\section{KESIMPULAN}

Berdasarkan uji sederhana yang dilakukan didapatkan bahwa tipe 7, yaitu tanah, lempung dan abu dengan bahan bakar sekam dan kayu memiliki kualitas terbaik. Kedua adalah tipe 1, yaitu tanah dengan bahan bakar kayu. Ketiga adalah tipe 5, yaitu tanah, lempung dan abu dengan bahan bakar sekam dan gergajian. Sedangkan yang kurang baik adalah tipe 2, 3, 4 (tanah, lempung dengan bahan bakar beragam).
Hal ini menunjukkan bahwa tanah dengan kualitas baik tanpa perlu campuran sudah bisa menghasilkan batu bata yang baik, dan penambahan abu sekam padi bisa meningkatkan kualitasnya. Sedangkan bahan bakar yang baik, salah satunya menggunakan kayu, meski begitu perpaduan kayu dan sekam menghasilkan kualitas yang baik pula.

Selain itu, hasil pemetaan menunjukkan bahwa batu bata berkualitas baik lebih banyak ditemukan di sisi timur peta. Hal ini sesuai dengan lokasi tipe 7 dan tipe 5 yang berada disisi timur, sedangkan tipe 1 di sisi barat, yang menunjukkan bahwa sisi timur dan barat Bantul memiliki ciri batu bata dan kualitas yang berbeda.

Pemahaman batu bata dalam komposisi pembentuk, bahan pembakar serta pengujian sederhana yang bisa dilakukan dengan cepat, mudah dan murah ini, bisa mempermudah dalam pemilihan batu bata di Bantul. Hal ini bisa bermanfaat dalam penggunaannya di bangunan, seperti pemilihan batu bata sebaiknya berasal dari area yang sama sehingga memiliki ukuran yang sama serta batu bata dengan kapasitas penyerapan lebih rendah serta kekuatan yang tinggi akan baik di sisi luar bangunan serta bagian pelingkup struktur.

\section{SARAN}

Penelitian batu bata sebaiknya dilakukan tidak saat musim hujan, karena akan lebih sulit mendapatkan sampel batu bata dalam kondisi kering akibat proses pengeringan yang lebih lama serta penyimpanan yang kurang terlindungi. Selain itu, pemilihan batu bata untuk pengujian lebih baik langsung setelah pembongkaran hasil pembakaran karena berada dalam kondisi terbaik.

Penelitian lanjutan bisa dilakukan dengan menambah jumlah tipe batu bata yang diteliti di Bantul, maupun difokuskan pada komposisi atau bahan bakar tertentu, ataupun alternatif bahan lain yang memungkinkan peningkatan kualitas batu bata di Bantul.

\section{DAFTAR PUSTAKA}

Amin, M. (2014). Inovasi Material pada Pembuatan Bata Merah Tanpa Dibakar untuk Kemakmuran Industri Kerakyatan. Inovasi dan Pembangunan-Jurnal Kelitbangan, 02(03), 1331.

Amir, M. Y., \& Basry, W. (2019). Pemanfaatan Kotoran Ternak Sapi dan Abu Sekam Padi sebagai Pengganti Sebagaian Tanah Liat untuk Meningkatkan Kualitas Batu Bata. Siimo Engineering. 3(1), 17-22. ISSN: 2581-1568.

Bapedal. (2008). Tabel Penambangan Batu Bata. Yogyakarta: Bapedal Kabupaten Bantul.

Direktorat Jenderal Cipta Karya. (1964). Bata Merah sebagai Bahan Bangunan NI-10. Bandung: 
Yayasan Lembaga Penyelidikan Masalah Bangunan.

Gencel, O., Erdugmus, E., Sutcu, M., \& Hulusi Oren, O. (2020). Effects of concrete waste on characteristics of structural fired clay bricks. Construction and Building Materials, 255, 112.

DOI: https://doi.org/10.1016/j.conbuildmat.2020.119 362

Handayani, S. (2010). Kualitas Batu Bata merah dengan Penambahan Serbuk Gergaji. Jurnal Teknik Sipil \& Perencanaan. 12(1), 41-50.

Kirkelund, G. M., Skevi, L., \& Ottosen, L. M. (2020). Electrodialytically treated MSWI fly ash use in clay bricks. Construction and Building Materials, 254, 1-11. DOI: https://doi.org/10.1016/j.conbuildmat.2020.119 286

Maidiawati, Sanada, Y., Konishi, D., \& Tanjung, J. (2011). Seismic Performance of Nonstructural Brick Walls Used in Indonesian R/C Buildings. Journal of Asian Architecture and Building Engineering, 10(1), 203-210. DOI: 10.3130/jaabe.10.203

Purwaningsih, S. (2006). Semen Putih Tiga Roda (White Cement). Warta Semen dan Beton Indonesia. 4(2), 24-27. ISSN: 1693-6655.

Rahmawati, A., \& Saputro, I. N. (2015). Penambahan Abu Jerami dan Abu Sekam Padi pada Campuran Batu Bata untuk Meningkatkan Kualitas dan Efisiensi Produksi Batu Bata Industri Tradisional. Eco Rekayasa. 11(1), 1622.

Syahland, S. J. (2016). Pengaruh Proses Pembuatan Batu Bata Merah asal Lampung terhadap Karakteristik Batu Bata yang dihasilkan. Inovasi dan Pembangunan - Jurnal Kelitbangan. 04 (1), 72-82.

Virdi, S. S. (2012). Construction Science and Materials. UK: Wiley-Blackwell.

Wibowo, Y. A., \& Santosa, T. S. (2017). Studi Pemetaan Industri Batu Bata di Kabupaten Bantul. Jurnal Riset Daerah. XVI (3), 28352858. 